\title{
$\mathrm{MSM}$ 의 경피 도포가 편심성 운동에 따른 근손상 발현 및 회복에 미치는 영향
}

조현덕 $\mathrm{MA}$, 김춘섭 $\mathrm{PhD}$, 김맹규 $\mathrm{PhD}$

경북대학교 체육교육과 스포츠의학실험실

\section{Effects of Transdermal Methylsulfonylmethane on Muscle Damage and Recovery Following Eccentric Exercise}

\author{
Hyeon-deok Jo MA, Choun-sub Kim PhD, Maeng-kyu Kim PhD \\ Sports Medicine Lab, Department of Physical Education, Kyungpook National University, Daegu, Korea
}

PURPOSE: The present study aimed to investigate the effects of transdermal application of methylsulfonylmethane (MSM) on muscle damage and recovery following eccentric exercise in young men.

METHODS: Eleven college-aged men without any cardiovascular or orthopedic disorders underwent two sessions consisting of a control session (CS) and an experimental session (ES) in a random order with at least 2 weeks of wash-out between the sessions. The participants performed 30 maximal eccentric exercises involving their non-dominant elbow flexors in each session. Circumference, muscle soreness, range of motion, maximal voluntary isometric contraction (MVIC), and muscular echo intensity (EI) were measured to evaluate the changes in the level of exercise-induced muscle damage (EIMD). All measurements were performed at 24, 48, 72, and 96 hours after exercise and also immediately before and after exercise.

RESULTS: Transdermal application of MSM in ES attenuated muscle swelling and decreased MVIC after eccentric exercise when compared with CS. Muscle soreness and EI tended to increase less rapidly and decrease more rapidly in ES than in CS.

CONCLUSIONS: Transdermal application of MSM may induce relatively positive effects on EIMD and recovery following eccentric exercise when compared with the treatment that has been widely used previously.

Key words: Transdermal, Methylsulfonylmethane, Menthol, Eccentric exercise, Exercise-induced muscle damage

\section{서 론}

체계적으로 프로그램화된 운동 트레이닝은 심혈관 질환을 포함한 대사 및 근골격계 장애 예방을 위한 1차적 중재전략으로 널리 권장되 어 왔다[1]. 특히 편심성 수축(eccentric muscle contraction)을 활용한 운동은 단축성(concentric) 수축 보다 심혈관 부담을 완화시키면서도
큰 힘을 발생시킬 수 있기 때문에 노인 및 심혈관 취약 집단에서도 효 율적인 트레이닝 요소가 될 수 있다[2]. 그러나 편심성 근수축을 함유 한 운동은 소위 운동 유발성 근손상(exercise-induced muscle damage, EIMD)으로 알려진 부정적 손상 징후를 초래할 수 있다[3-5]. EIMD 발 현에 따라 관절가동범위(range of motion, ROM) 및 최대 자발적 등척 성 수축(maximal voluntary isometric contraction, MVIC) 근력 저하로

Corresponding author: Maeng-kyu Kim Tel +82-53-950-5937 Fax +82-53-955-4235 E-mail kimmkaknu.ac.kr *본 논문은 조현덕 석사학위논문의 일부를 수정 보완한 것으로, (주)미스미네랄의 재원에 의하여 지원되었음(202002950000). Keywords 경피도포, 식이유황, 멘톨, 편심성 근수축, 운동 유발성 근손상

Received 15 Jan 2021 Revised 9 Feb 2021 Accepted 10 Feb 2021 
인해 운동 수행력이 저하될 수 있으며, 운동 후 24 시간부터 점차 발생 하여 96시간 이상 지속될 수 있는 지연성근통증(delayed onset muscle soreness, DOMS)으로 인해 훈련 프로그램으로부터 이탈을 초래할 수 있다[6,7]. 이는 엘리트 선수들은 물론 특히 운동 초보자에서 더욱 심 각한 증상을 유발하기 때문에, EIMD의 예방 및 치료를 위한 대안을 마련하는 것은 임상 스포츠 현장에서 유의미한 정보를 제공하는데 도 움이 될 수 있다.

EIMD 발생은 통상 편심성 수축의 독특한 수축 형태에 기인하는데, 근섬유(muscle fiber)에 대한 외부 하중이 직접적인 원인으로 작용하 여 편심성 근수축 동안 근절(sarcomere)이 불균일하게 늘어나고, 이로 인해 일부 근필라멘트(myofilament)에서 액틴과 미오신 간 중첩 부위 가 사라진다. 결과적으로 근절 내 구조 단백질들은 더 많은 장력을 받 아 Z-band의 유동을 발생시키고 그로 인해 근절의 구조 단백질이 붕 괴된다 $[8,9]$. 이후 대사적 손상이 뒤따르고 분해된 단백질들은 혈액으 로 유출되어 일련의 염증 반응을 일으키며, 궁극적으로 EIMD로부터 완전한 회복 및 재생 과정은 수 일 또는 수 개월에 걸쳐 일어난다 $[9,10]$.

EIMD의 예방 혹은 치료를 위한 접근법으로 마사지(massage), 스트 레칭(stretching), 수침요법(hydrotherapy), 한랭요법(cryotherapy) 및 약 물 복용(drug oral administration) 등과 같은 다양한 임상 전략들이 많 은 연구들에서 검증되었지만[11], 실제 어떤 기법도 그 유효성이 체계적 으로 정립되지 못했다. 이는 EIMD의 불명확한 발생 및 회복 메커니즘, 혹은 개인 간 차이에 의한 것으로 여겨진다. 이러한 상황에서 손상 근 육에 대한 직접적인 처치법으로써 경피 도포(transdermal administration)를 이용한 보충 및 대체 의학적 처치법은 경구 복용에 따른 부작 용을 최소화하면서 항염증 및 항산화 효과를 효율적으로 적용할 수 있는 방법으로 제안될 수 있다[12]. 경피 도포를 통한 치료 제재 투여 는 손상 부위에 직접 적용할 수 있기 때문에 국소 부위를 효과적으로 표적화 할 수 있다[13,14]. 따라서 편심성 근수축에 의한 근손상을 효율 적으로 통제할 수 있는 치료 또는 보충 물질의 경피 도포 기법은 EIMD의 예방 및 치료를 위한 실용적 대안이 될 수 있다.

멘톨(menthol)은 강력한 냉각(cooling) 효과를 만들어[15], EIMD의 발현을 완화시키고 회복을 촉진하기 위한 목적으로 널리 이용되어온 성분이다. 그러나 손상 후 근기능 유지에 있어서 멘톨의 효과는 운동 에 이용된 근육군 혹은 손상 유도를 위한 운동 프로토콜에 따라 상충 된 결과들이 보고되었으며[14,16], 사실상 EIMD의 발현 완화 및 회복 을 위한 대체 의학적 처치로 멘톨 사용의 적합성 여부는 여전히 불분 명하다.

한편 식이유황(methylsulfonylmethane, MSM)은 전염증성 사이토 카인(pro-inflammatory cytokines)의 발현을 약화시키고, 반응성 산소 종(reactive oxygen species)과 같은 자유라디칼(free radicals)에 의한 산 화스트레스(oxidative stress)를 억제하는 것으로 알려져 있다[17]. EIMD
의 제증상들이 염증 과정 및 산화 스트레스와 부분적으로 관련한다 는 점에서 몇몇 관련 연구들은 MSM의 경구 복용에 따른 전신 순환적 기전을 통해 근손상 완화를 기대하였으며, 실제로 일부 연구들에서 $\mathrm{MSM}$ 이 급성 운동 후 염증 혹은 산화스트레스를 완화시킨다는 긍정 적인 결과들이 보고되었다[18-20]. 그러나 EIMD의 주요 증상인 근통 증 혹은 근육 기능 변화에서 $\mathrm{MSM}$ 의 효과는 연구 간 상반된 결과들 을 보고하였다[18-20]. 이는 경구 복용에 의한 MSM의 전신 순환적 적 용이 EIMD에 대한 효과적 대응에 한계가 있음을 나타낸다.

$\mathrm{MSM}$ 이 EIMD의 발현 완화에 있어서 긍정적 효과를 나타낸다는 점[18-20] 그리고 경피 도포가 효율적인 근손상 처치전략이 될 수 있다 는 보고에도 불구하고[14,21,22], 지금까지 EIMD의 발현 양상에 대한 MSM 경피 도포의 영향을 구명한 연구는 국내외적으로 전무하다. 따 라서 MSM의 국소 경피 도포가 EIMD의 발현 양상 및 회복 정도에 미 치는 영향을 탐색하는 것은 EIMD의 효율적 대처 전략을 탐색하는 것 은 물론 MSM의 잠재적 효과에 대한 새로운 이해를 도출하는 데 기여 할 것으로 사료된다.

\section{연구 방법}

\section{1. 연구 대상}

연구 참여자 모집을 위해 $\mathrm{D}$ 광역시 소재 $\mathrm{K}$ 대학 홈페이지 광고를 이 용하여 남자 재학생들을 모집했다. 미국스포츠의학회(American College of Sports Medicine)에서 제공하는 한국어판 운동 참여 전 신체활 동 준비설문지(Physical Activity Readiness Questionnaire, PAR-Q) [23] 및 미국 심장협회(American Heart Association, AHA)의 건강/체력 시 설 참여 전 검진 설문지(Health/Fitness Facility Pre-participation Screening Questionnaires)를 통해 심혈관 질환 및 정형외과적 문제가 없는 인원을 사전 선별하였다. 본 연구에서 근손상을 발현하기 위한 운동 모형은 규칙적인 신체활동에 영향을 받을 수 있다. 따라서 실험 참여 전 최소 12 개월 동안 저항운동을 포함한 모든 유형의 정규화된 운동 프로그램에 참여한 경우 연구 대상에서 제외되었다. 그 외 구체 적인 제외기준은 다음과 같다. i) 심뇌혈관 및 정형외과적 질환이 있 는 자; ii) 당뇨병, 고혈압을 포함한 대사질환이 있는 자; iii) 실험 참여 최소 12 개월 전 또는 현재 의사 처방에 따른 약물 복용자; iv) 과도한 비만자(체질량지수 $>30 \mathrm{~kg} / \mathrm{m}^{2}$ ); v) 기타 연구자가 부적합하다고 판단 되는 자.

연구자는 연구 참여에 따른 이득 및 부작용 등을 참여자에게 상세 히 설명하고, 자발적 참여 의사를 가지는 17 명의 인원을 우선 선발하 였다. 그 중 중도 이탈자 $(\mathrm{n}=3)$ 및 비정상적 근력 반응을 나타낸 자 $(\mathrm{n}=3)$ 를 제외한 총 11 명을 대상으로 통계분석을 수행하였다. 참여자들 의 임상적 특성은 Table 1 과 같다. 


\section{2. 연구절차}

\section{1) 연구설계}

$\mathrm{MSM}$ 경피 도포가 편심성 근수축에 동원된 국소 근육의 EIMD 발 현 정도 및 회복 양상에 미치는 영향을 조사하기 위해, 현재 연구는 위 약 대조(placebo controlled)의 단일맹검(single-blind)을 적용한 무작위 교차설계(randomized cross-over design)로 수행되었다. 참가자들은 팔 꿈치 굴곡근을 이용한 최대 편심성 운동 후 멘톨이 주성분인 대조 물 질(control session, CS) 또는 멘톨과 MSM이 주성분인 실험 물질(experimental session, ES)을 표적 근육에 적용하는 두 번의 실험 세션에 무 작위 순서로 참여하였으며, 각 세션은 최소 2주 이상 세척 기간(washout period)으로 분리되었다. EIMD의 발현 정도 및 회복 경로는 근육 의 통증과 부종, 힘 발생 능력과 관절가동범위 그리고 영상학적 변화 와 같은 간접적인 근손상 표지자를 통해 확인되었다. 모든 측정 변수 는 운동 전 및 직후를 포함하여 운동 후 $24,48,72$ 그리고 96시간에서

Table 1. Clinical characteristics of subjects $(n=11)$

\begin{tabular}{lrcc}
\hline Variables & \multicolumn{1}{c}{ CS } & ES & $p$ \\
\hline Age (yr) & $21.64 \pm 0.65$ & - & N.S \\
Body composition & & & \\
$\quad$ Height (cm) & $172.82 \pm 1.57$ & $172.92 \pm 1.60$ & .477 \\
Weight (kg) & $64.99 \pm 2.21$ & $65.02 \pm 2.23$ & .943 \\
BMI (kg/m²) & $21.77 \pm 0.68$ & $21.74 \pm 0.65$ & .749 \\
WHR & $0.84 \pm 0.01$ & $0.85 \pm 0.01$ & .215 \\
Body fat (\%) & $14.73 \pm 1.03$ & $14.46 \pm 0.95$ & .863 \\
Hemodynamic parameters & & & \\
SBP (mmHg) & $115.45 \pm 5.07$ & $117 \pm 2.67$ & .562 \\
DBP (mmHg) & $69.91 \pm 3.86$ & $71.45 \pm 1.77$ & .594 \\
MAP (mmHg) & $85.09 \pm 4.22$ & $86.64 \pm 1.51$ & .563 \\
MHR (beats/min) & $69.45 \pm 4.81$ & $69.55 \pm 4.12$ & .948 \\
\hline
\end{tabular}

Values are means \pm SEM.

BMI, body mass index; WHR, waist-to-hip ratio; SBP, systolic blood pressure; DBP, diastolic blood pressure; MAP, mean arterial pressure; MHR, mean heart rate.

$p$ values are calculated by Wilcoxon's signed-ranks test.
각각 획득하였다. 본 연구의 실험 절차는 Fig. 1과 같다.

본 연구 프로토콜은 K대학교 생명윤리심의위원회(Institutional Review Board, IRB)를 통해 연구윤리에 관한 검토 및 승인을 취득하였으 며(승인번호: 2020-0037), 연구자들은 연구의 목적, 절차, 수반되는 위 험 및 참여에 따른 이득을 모든 참여자에게 상세히 설명한 후 IRB로부 터 승인된 서면동의서에 서명을 획득하였다.

\section{2) 편심성 운동 프로토콜}

팔꿈치 굴곡근의 편심성 수축은 사전 측정된 MVIC 값의 $100 \%$ 부 하로 설정된 덤벨(dumbbell)을 이용하여 비우세측 팔에서 수행되었다. 각각의 수축은 팔꿈치 관절이 $50^{\circ}(0.87 \mathrm{rad})$ 에서 $170^{\circ}(2.97 \mathrm{rad})$ 범위까 지 5초에 걸쳐 일정한 속도로 덤벨이 아래로 내려가는 편심성으로 수 행되었으며, 시작 위치로 덤벨을 들어 올릴 경우 참여자가 단축성 수 축 힘을 발휘하지 않도록 검사자들이 보조하였다. 반복된 수축 간 45 초 휴식과 함께 총 30 회 편심성 근수축을 실시하였다[24].

\section{3) 중재 처치}

$3.65 \%$ 멘톨을 주성분으로 하는 대조 물질(CS, 제품 $\mathrm{B}$ 사), $3.65 \%$ 멘톨 과 함께 $10 \% \mathrm{MSM}$ 이 함유된 실험 물질(ES, 제품 $\mathrm{M}$ 사)은 각각 시각적 으로 식별이 불가한 별도의 용기에 주입(단일 맹검용)하여 각 참여자 들에게 제공되었다. 구체적으로 본 연구의 독립변인 물질로서 대조물 질과 실험물질은 첫째, 색상에서의 차이는 거의 식별이 불가능하다. 둘 째, 후각자극의 향은 차이가 없다. 따라서 참여자가 대조물질과 실험 물질의 구별 인식하는 것이 어렵다고 판단된다.

각 세션에서 편심성 운동 직전을 포함해 운동 후 하루 3 회씩(아침, 실험실 방문 시 그리고 저녁 9시 이후; $5 \mathrm{~mL}$ 회 도포) 대조 물질 또는 실험 물질을 도포하도록 지시하였다; 96 시간째에는 기상 후 1 회 즉 최 종 측정 전에만 적용하도록 지시하였다. 해당 세션에서 제공받은 물질 을 팔꿈치 굴곡근의 근복과 함께 기시부 및 정지부 근건접합부(musculotendinous junction)에 흡수시키기 위해 최대 10 분 동안 도포하도

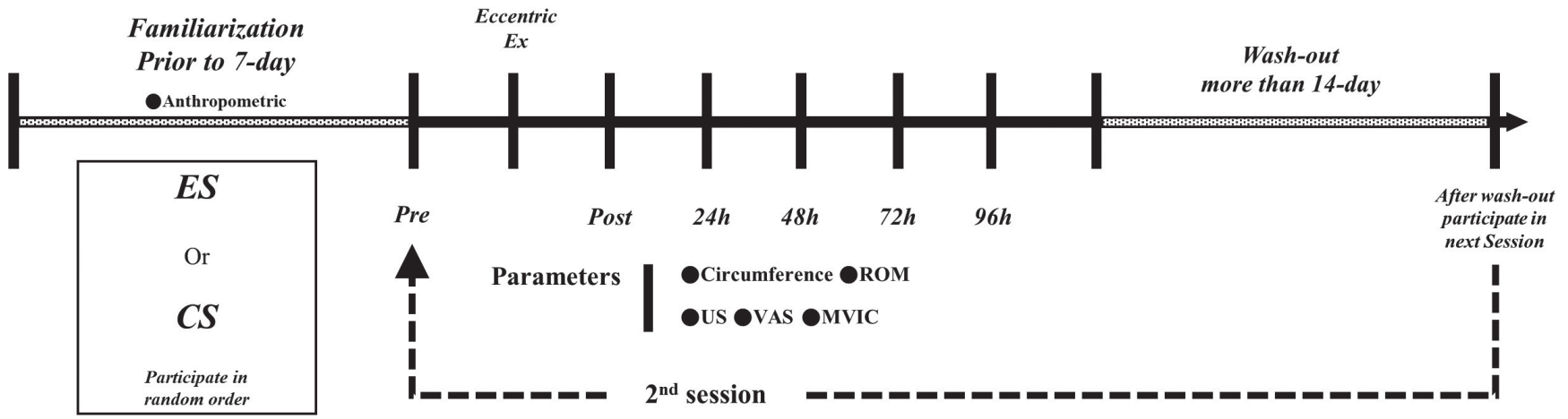

Fig. 1. Schematic illustration of the study. ROM, range of motion; US, ultrasonography imaging; VAS, visual analogue scale; MVIC, maximal voluntary isometric contraction; $\mathrm{CS}$, control session; $\mathrm{ES}$, experimental session. 
록 지시하였으며[14], 압력에 의한 외부적 영향(예를 들어 마사지 효과) 를 최소화하기 위해 가볍게 도포하도록 지시하였다.

\section{3. 측정방법 및 변인}

\section{1) 상완둘레}

편심성 운동 후 근육 부종 변화를 평가하기 위해 Gulick anthropometric 측정 테이프(Baseline anthropometric measuring tape, Fabrication Enterprises Inc., White Plains, NY)을 이용해 상완의 원위부, 중위 부 및 근위부 둘레를 각각 측정하였다. 구체적으로 바로 선 자세에서 팔을 늘어뜨리고 있는 동안 팔꿈치 주름 위 $4 \mathrm{~cm}$ (distal portion), 팔꿈 치 주름과 견봉 사이 $30 \%$ 지점(middle portion) 및 50\% 지점(proximal portion)에서 측정하였다. 모든 측정 구간에서 측정의 재현성을 확보하 기 위해 반영구적 잉크펜으로 측정 위치를 표시하고 2회 측정 후 평균 값을 채택하였다[25].

\section{2) 근육통증}

EIMD로 유발된 DOMS는 일반적으로 휴식 시 보다 근육의 수축 즉 움직임을 수행할 때 활성화되는 특성이 있다[26]. 따라서 본 연구에 서는 최대 신전 및 굴곡 시 발현되는 통증 정도를 평가하였다. 근통증 수준을 평가하기 위해 100-mm visual analogue scale (VAS)를 활용하 였으며, 참여자들은 관절가동범위를 측정하는 동안 최대 신전 및 굴 곡 시 인지된 통증을 VAS에 기록하였다. 구체적으로 최대 신전 시 통 증은 어깨 외전(abduction) 각을 $0^{\circ}$ 로 유지하며 팔꿈치 관절을 최대한 펼 때 인지된 통증을 기록하였으며, 최대 굴곡 시 통증은 손바닥이 어 깨에 최대한 닿도록 노력할 때 인지된 통증으로 기록되었다[27]. 정확 한 통증 인지를 위해 각 측정 간 최소 30 초의 휴식기를 부여하였으며 2회 측정의 평균 값을 이용해 자료분석을 수행하였다.

\section{3) 관절가동범위}

인체 측정용 고니오미터(Baseline Goniometer, Fabrication Enterprises Inc., White Plains, NY)를 이용해 자발적 최대 굴곡 시(joint angle of voluntary maximal flexion, FLX) 및 자발적 최대 신전 시 각도(joint angle of voluntary maximal extension, EXT)를 측정하고, EXT에서 FLX를 감산한 값을 $\mathrm{ROM}$ 척도로 이용했다[7]. $\mathrm{ROM}$ 측정 시 어깨 관절의 외 전 및 굴곡 각은 모두 $0^{\circ}$ 로 설정하고, EXT는 선 자세로 팔을 늘어뜨리 고 있는 동안 팔꿈치 관절의 최대 신전 시 각을, FLX는 동일한 자세에 서 손바닥을 동측 어깨에 닿도록 시도할 때의 각으로 각각 설정하였 다. 팔꿈치 관절에 대한 $\mathrm{ROM}$ 측정의 재현성 확보를 위해 반영구적 잉 크펜을 이용해 상완골(humerus) 외측상과(lateral epicondyle), 견봉돌 기(acromion process) 및 요골 경상돌기(styloid process of the radius)를 각각 표시하였고, 모든 측정은 2회 실시 후 평균 값을 채택하였다.

\section{4) 최대 자발적 등척성 수축 근력}

팔꿈치 굴곡근의 MVIC 토크 값을 평가하기 위해 편심성 운동 시 이용된 preacher curl 벤치에 앉아 인체측정용 고니오미터를 이용해 어 깨 관절의 $45^{\circ}$ 굽힘과 $0^{\circ}$ 외전 각에서 $90^{\circ}(1.57 \mathrm{rad})$ 의 팔꿈치 관절 각을 유지하도록 지시했다. 참여자의 손목을 force gauge (SS300, SEWHAC$\mathrm{NM}$, Bucheon, Korea)와 연결된 스트립으로 고정하고 3초 동안 발휘하 는 MVIC 토크 값을 digital recorder(AD-4321C, A \& D Company Ltd, Tokyo, Japan)를 통해 확인하였다. 측정은 45초 휴식과 함께 총 3회에 걸쳐 실시하며 추출된 값 중 최대치를 통계분석에 이용했다[24]. 참여 자들이 최대한의 노력을 발휘할 수 있도록 구두 격려를 제공하였다.

\section{5) 초음파 영상분석}

근육 초음파 영상 추출을 위해 4-16 MHz의 $50 \mathrm{~mm}$ 선형 탐촉자 (linear probe)를 장착한 초음파 기기(S12, SonoScape Co., Shenzhen, China)를 이용해 B 모드(B-mode) 이미지를 추출했다. 구체적으로 탐 촉자를 팔꿈치 주름과 견봉 사이 $30 \%$ 지점에 위치하여 근육 횡단면 영상을 수집하였으며, 측정 중 참여자는 바로 누운 자세에서 안정 상 태를 유지하도록 지시하였다. 모든 측정 동안 초음파 시스템의 밝기 (gains, 59), 주파수(frequency, 9.1-13 MHz), 초점(focus, $2.5 \mathrm{~cm}$ ) 및 깊이 (depth, $5 \mathrm{~cm}$ )를 동일하게 유지하였다. 세 차례 반복 추출된 이미지 중 근육 반향세기 값이 가장 유사한 2 개 이미지를 자료분석에 이용하였 다[6,28]. 분석용 추출 이미지는 $1,024 \times 768$ 해상도의 TIF 형식으로 디 지털화한 뒤, Image J 소프트웨어(version 1.52a, National Institutes of Health, Washington, USA)을 이용하여 $10 \times 10 \mathrm{~mm}$ 의 동일한 관심영역 (region of interest, ROI) 내 근육 초음파 반향세기(echo intensity, EI)를 확인하였다. ROI는 상완골(humerus), 격막(septum) 및 근막(fascia)을 포함하지 않도록 하되 영상 내 landmark를 기반으로 목표 근육만을 대상으로 설정하였고, EI는 회색조 히스토그램 분포(greyscale histogram distribution, 0 = black to 255 = white)의 평균을 채택하였다.

\section{4. 자료처리방법}

모든 자료 처리는 IBM사의 윈도우용 SPSS Statistics (Statistical Package for the Social Sciences software, versions 25.0, Chicago, IL, USA) 프 로그램을 사용하여 각 항목별 평균(mean)과 표준오차(standard error of mean, SEM)를 산출하였다. Shapiro-Wilk test를 이용해 표본의 정규 분포를 확인하고 Levene's test로 분산의 동질성(homogeneity of variance)을 판별하였다. 각 세션 내 baseline 값에서 운동 직후를 포함한 회복기 모든 종속변수들의 변화를 검증하기 위해 Bonferroni post hoc test와 함께 일원배치분산분석[one-way analysis of variance (ANOVA)] 을 실시하였다. 시간에 따른 세션 간 상호작용(interaction) 효과를 검 출하기 위해 이원반복측정분산분석(two-way repeated measures ANO- 


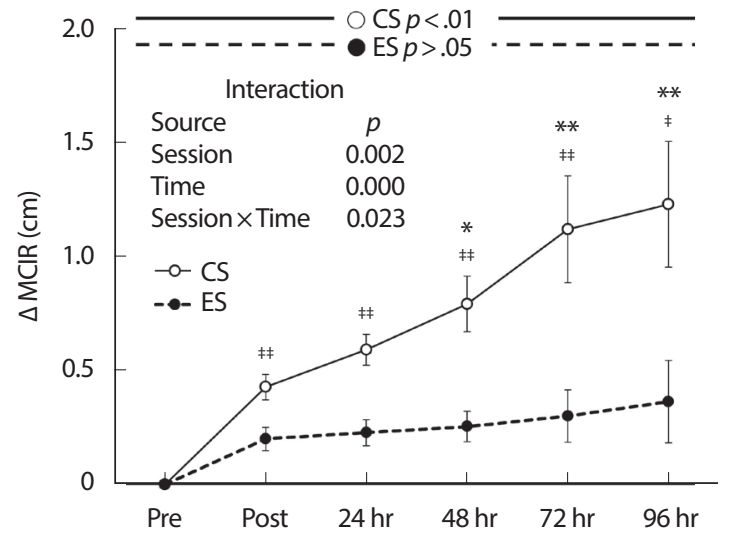

Fig. 2. Changes of circumference at middle portion. MCIR, mid portion circumference; CS, contrast session; ES, experimental session. $p$ values are calculated by one-way analysis of variance (ANOVA). Interaction is examined by repeated measures ANOVA. ${ }^{*} p<.05$ and ${ }^{* *} p<.01$ indicate significant differences between baseline and each measure time in CS session, which were analyzed by one-way ANOVA followed by Bonferroni's post hoc test. ${ }^{\ddagger} p<.05$ and ${ }^{\ddagger \neq} p<.01$ indicate significant differences between the $\mathrm{ES}$ and CS, which was analyzed by Wilcoxon signed-rank test.

$\mathrm{VA)}$ 을 활용하였으며, 특정 변수에서 유의한 상호작용효과가 있을 경 우, 각각의 시간 포인트에서 측정변인 간 차이를 탐지하기 위해 Wilcoxon signed-rank test를 이용하였다. 모든 통계적 유의수준 $\alpha=.05$ 미 만으로 설정하였다.

\section{연구 결과}

\section{1. 근육 형태학적 변화 및 통증 변화}

상완 원위부 둘레의 경우 $\mathrm{CS}$ 와 $\mathrm{ES}$ 는 72 그리고 96 시간에서 운동 전 과 비교하여 통계적으로 유의하게 증가하였지만( $p<.05$, respectively), 시간 경과에 따른 세션 간 유의한 상호작용 효과는 나타나지 않았다 (data not shown). 중위부의 경우 CS만 48, 72 그리고 96시간에서 운동 전과 비교하여 통계적으로 유의하게 증가하였으며 $(p<.05$, respective$\mathrm{ly})$, 시간 경과에 따른 세션 간 유의한 상호작용 효과가 나타났다. 또한, 운동 직후를 포함해 $24,48,72$ 및 96시간에서 CS와 ES 간 통계적으로 유의한 차이가 나타났다( $p<.05$, respectively; Fig. 2$)$. 근위부의 경우 CS 만 운동 직후를 포함해 $24,48,72$ 그리고 96시간에서 운동 전과 비교 하여 통계적으로 유의하게 증가하였으며( $p<.05$, respectively), 시간 경 과에 따른 세션 간 유의한 상호작용 효과가 나타났다. 또한, $24,48,72$ 및 96시간에서 CS와 ES 간 통계적으로 유의한 차이가 나타났다 $(p<.05$, respectively; Fig. 3$)$.

편심성 운동 후 상완 신전 및 굴곡 시 발생하는 주관적 근통증의 수 준을 평가한 결과는 다음과 같다. 신전 시 CS는 72시간에서 운동 전과 비교하여 통계적으로 유의하게 증가하였지만( $p<.05)$, ES는 운동 전과

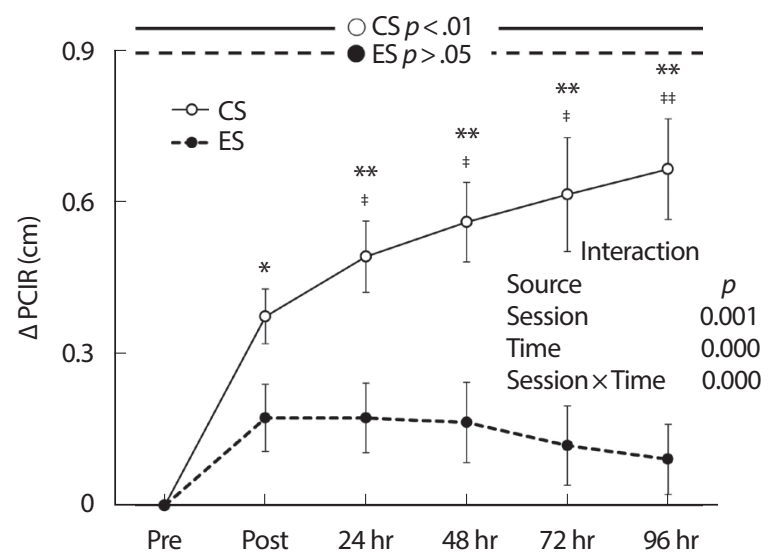

Fig. 3. Changes of circumference at proximal portion. PCIR, proximal portion circumference; $C S$, contrast session; $\mathrm{ES}$, experimental session. $p$ values are calculated by one-way analysis of variance (ANOVA). Interaction is examined by repeated measures ANOVA. ${ }^{*} p<.05$ and ${ }^{* *} p<.01$ indicate significant differences between baseline and each measure time in CS session, which were analyzed by one-way ANOVA followed by Bonferroni's post hoc test. ${ }^{\ddagger} p<.05$ and ${ }^{\ddagger \ddagger} p<.01$ indicate significant differences between the ES and CS, which was analyzed by Wilcoxon signed-rank test.

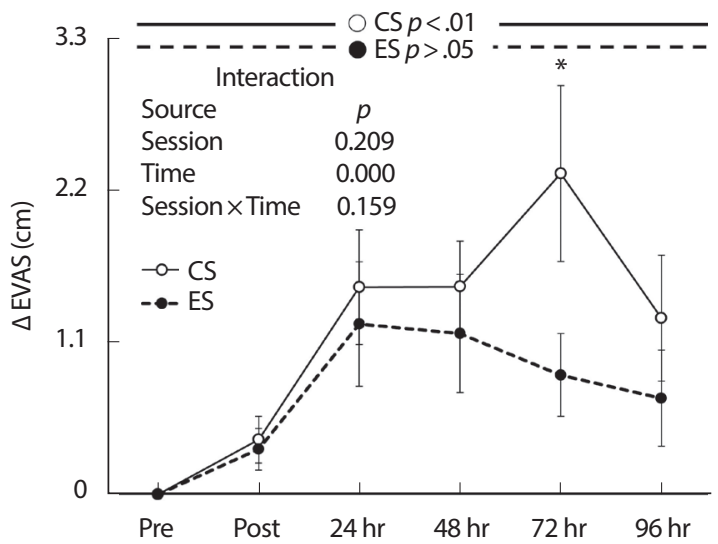

Fig. 4. Changes of muscle soreness during extension. EVAS, extension visual analogue scale; $C S$, contrast session; $E S$, experimental session. $p$ values are calculated by one-way analysis of variance (ANOVA). Interaction is examined by repeated measures ANOVA. ${ }^{*} p<.05$ and indicate significant differences between baseline and each measure time in CS session, which were analyzed by one-way ANOVA followed by Bonferroni's post hoc test.

비교하여 통계적으로 유의한 차이가 나타나지 않았다( $p>.05)$. 하지만, 시간 경과에 따른 세션 간 유의한 상호작용 효과는 나타나지 않았다 (Fig. 4). 굴곡 시 발생하는 통증의 경우 CS와 ES 모두 24, 48 그리고 72 시간에서 운동 전과 비교하여 통계적으로 유의하게 증가하였지만 ( $p<.05$, respectively), 시간 경과에 따른 세션 간 유의한 상호작용 효과 는 나타나지 않았다(data not shown).

\section{2. 근육 기능적 특성 변화}

편심성 운동으로 인한 ROM의 변화를 평가한 결과는 다음과 같다. 


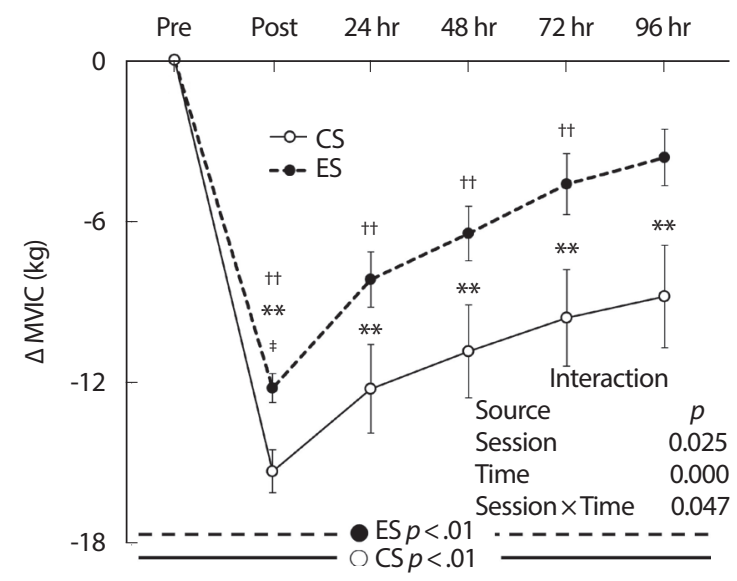

Fig. 5. Changes of MVIC. MVIC, maximal voluntary isometric contraction; $\mathrm{CS}$, contrast session; ES, experimental session. $p$ values are calculated by one-way analysis of variance (ANOVA). Interaction is examined by repeated measures ANOVA. ${ }^{* *} p<.01$ indicate significant differences between baseline and each measure time in CS session, which were analyzed by one-way ANOVA followed by Bonferroni's post hoc test. ${ }^{+\dagger} p<.01$ indicate significant differences between baseline and each measure time in ES, which were analyzed by one-way ANOVA followed by Bonferroni's post hoc test. ${ }^{\ddagger} p<.05$ and indicate significant differences between the ES and $\mathrm{CS}$, which was analyzed by Wilcoxon signed-rank test.

$\mathrm{CS}$ 는 운동 직후를 포함해 $24,48,72$ 및 96시간에서, $\mathrm{ES}$ 는 운동 직후를 포함해 24,48 시간에서 운동 전과 비교하여 통계적으로 유의하게 감소 하였다 $(p<.05)$. 하지만 시간 경과에 따른 세션 간 유의한 상호작용 효 과는 나타나지 않았다(data not shown).

편심성 운동으로 인한 MVIC의 변화를 평가한 결과는 다음과 같다. $\mathrm{CS}$ 는 운동 직후를 포함해 24, 48, 72 및 96시간에서, $\mathrm{ES}$ 는 운동 직후를 포함해 24,48 및 72 시간에서 운동 전과 비교하여 통계적으로 유의하 게 감소하였다 $(p<.05$, respectively). 또한, 시간 경과에 따른 세션 간 유 의한 상호작용 효과가 나타났으며, 운동 직후에서 CS와 ES 간 통계적 으로 유의한 차이가 나타났다 $(p<.05$, Fig. 5).

\section{3. 근육 초음파 반향세기 변화}

$\mathrm{CS}$ 는 ES에 비해 운동 직후부터 96시간까지 $\mathrm{EI}$ 증가가 더 높은 경향 을 나타냈다. 게다가 CS에서 팔꿈치 굴곡근의 EI는 통계적으로 유의하 게 증가하였으나 $(p<.05)$, 이와 대조적으로 $\mathrm{ES}$ 에서 $\mathrm{EI}$ 는 측정 시기내 유 의미한 변화를 나타내지 않았다( $p>.05)$. 그러나 세션 간 시간에 따른 유의한 상호작용 효과는 나타나지 않았다( $p=.10$, Fig. 6).

\section{논 의}

본 연구는 건강한 남자 대학생을 대상으로 편심성 운동 전후 MSM 제재의 국소적 경피 도포가 EIMD의 발현 정도 및 회복 양상에 미치

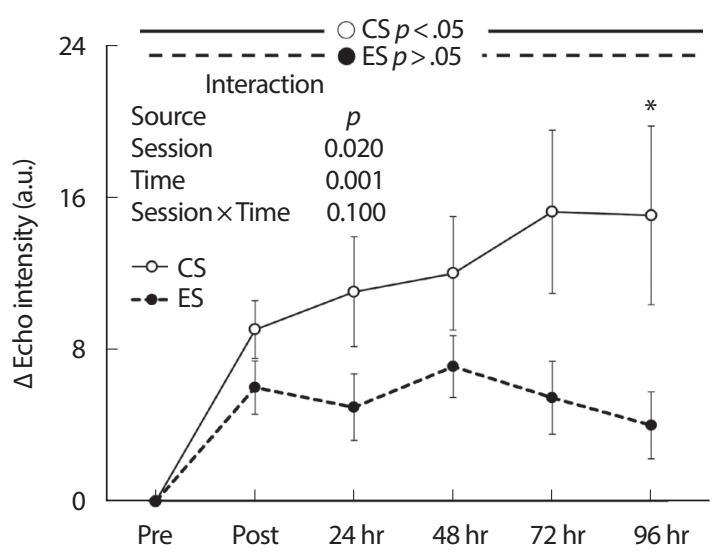

Fig. 6. Changes of muscular echo intensity in ultrasound imaging. El, echo intensity; $\mathrm{CS}$, contrast session; $\mathrm{ES}$, experimental session. $p$ values are calculated by one-way analysis of variance (ANOVA). Interaction is examined by repeated measures ANOVA. ${ }^{*} p<.05$ and indicate significant differences between baseline and each measure time in CS session, which were analyzed by one-way ANOVA followed by Bonferroni's post hoc test.

는 영향을 구명하려는 목적으로 수행되었으며 주된 연구결과는 다음 과 같다. 첫째, MSM 경피 도포는 대조물질에 비해 팔꿈치 굴곡근의 편심성 운동 후 근육 부종 발생을 약화시킬 뿐만 아니라 신속하게 감 소시키는 것으로 나타났으며, 근통증 또한 MSM 적용에 따라 비교적 빠르게 줄어드는 경향이 있었다. 둘째, MSM 경피 도포는 편심성 운동 직후 힘 발생 능력의 저하를 완화하고 근력 회복을 촉진하는 것으로 나타났다. 셋째, 편심성 근수축 후 팔꿈치 굴곡근의 반향세기는 대조 물질과 비교해 MSM 적용에서 운동 직후 더 적게 증가하고 더 빠르게 감소하는 경향이 있었다.

팔꿈치 굴곡근에서 편심성 운동을 실시할 경우 운동 후 96시간까지 상완 둘레가 증가할 수 있으며, 상완둘레 증가는 $\mathrm{EIMD}$ 의 대표적 간접 표지자인 부종의 발생여부를 판단할 수 있는 유용한 지표이다[6]. 흥미 롭게도 본 연구결과는 대조 물질과 비교해 MSM 적용 시 중위부 및 근 위부의 상완 둘레가 운동 직후 덜 증가할 뿐 아니라 기준선으로 빠르 게 회복한다는 것을 나타낸다. 현재 연구에서 MSM 적용에 따른 근육 부종 변화를 설명할 수 있는 생리학적 지표는 평가되지 않았지만 근 육 부종이 면역 및 염증 반응과 관련한다는 것은 이미 잘 알려진 사실 이다[8,10]. 현재까지 보고된 MSM의 대표적인 생물학적 효과 중 하나 가 염증을 감소시킨다는 점에서[17] 본 연구의 결과는 편심성 운동 후 팔꿈치 굴곡근을 표적으로 한 MSM의 경피 도포가 염증 반응을 완화 를 통해 근육 부종 발현을 약화시켰을 가능성을 시사한다.

편심성 운동 후 근통증 즉 DOMS는 휴식 시에 비해 표적 근육에 압력이 적용되거나 특히 근수축을 수반하는 움직임이 발생할 때 더욱 민감해진다[26,27]. 이 같은 DOMS의 특성을 고려하여 본 연구에서도 신전 및 굴곡 시 통증을 평가하였다. 그 결과 세션 간 통계적 차이는 없 
었으나 대조물질의 경우 신전 및 굴곡 시에 통증의 유의미한 증가가 있었던 반면 ES 측정 기간 동안 신전 시 발생한 근통증에서 운동 전과 비교하여 통계적 차이는 나타나지 않았다. 편심성 근수축에 따라 발현 되는 DOMS의 발생 메커니즘에 관한 과학적 증거가 불분명하기 때문 에 $[29,30]$ MSM에 의한 DOMS 완화를 설명할 수 있는 명확한 기전을 설명하는 데 한계가 있다. 그러나 본 연구에서 대조물질로 활용한 멘 톨 성분이 근통증 완화를 목적으로 임상 및 스포츠 현장에서 널리 이 용된다는 사실에 주목할 필요가 있다[14]. 사실상 본 연구는 MSM의 부가적 투여가 멘톨 단독처치에 비해 근통증 완화에 더 긍정적인 효 과를 미칠 수 있다는 사실을 나타내고 있으며, 따라서 DOMS로부터 의 회복을 촉진하기 위한 새로운 전략으로써 MSM의 경피 도포가 반 드시 시도될 필요가 있다는 사실을 강조하고 있다.

MVIC 토크는 EIMD 발현에 따른 인체 분절의 힘 발생 능력을 평가 하기 위해 널리 이용되어온 지표로써 편심성 운동 직후 급격한 감소와 함께 지연된 회복 양상을 나타낸다[6,7]. 현재 연구의 결과는 편심성 근 수축 직후 MVIC 토크의 급격한 저하가 멘톨 단독처치보다 MSM 추 가 투여를 통해 완화될 수 있을 뿐만 아니라 MSM이 근력 회복을 촉 진한다는 사실을 나타낸다. 게다가 편심성 운동 후 ROM 저하 또한 통 계적으로 유의하지는 않았지만 MSM의 경피 도포를 통해 경감되는 경향이 나타났다. 근 기능 저하가 EIMD에서 간과할 수 없는 주요 징 후이며, 특히 관절가동범위 및 힘 발생능과 같은 근골격계 기능의 감 소가 원활한 운동 수행에 악영향을 미칠 수 있다는 점에서[31], MSM 의 경피 도포가 편심성 운동 후 운동 수행능력 보존 및 회복에 도움이 될 수 있다는 사실은 엘리트 선수 및 운동 참여자에게 매우 흥미로운 정보가 될 수 있다. 추후 연구는 MSM 경피 도포가 EIMD 발현 동안 운동 수행에 미치는 긍정적 효과를 설명할 수 있는 생리학적 기전을 밝히기 위해 반드시 수행되어야 한다.

초음파 반향세기의 증가는 근육 내 구조 단백질 붕괴, 근육 세포 내 체액 침투 그리고 근섬유 간 공간 팽창(oedema)과 관련할 수 있다고 알려져 있다[32]. 이미 다수의 연구들에서 편심성 운동 후 근육 반향세 기를 통해 EIMD의 발생 또는 심각성을 판단하였으며 $[6,33]$, 팔꿈치 굴 곡근을 이용한 편심성 운동 후 $\mathrm{EI}$ 는 심지어 운동 후 120 시간까지 지속 적인 증가를 보여주었다[6]. 본 연구의 결과에서도 팔꿈치 굴곡근의 편 심성 근수축 후 근육 반향세기는 모든 세션에서 증가하는 경향이 나 타났다. 게다가 근육 반향세기는 멘톨 단독 처치에서는 통계적으로 유 의하게 증가하였다. 비록 현재 연구에서 위약(placebo) 효과를 배제하 기 위해 처치가 없는 조건을 설정하지 않았기 때문에 멘톨 적용과 비 적용에 따른 근육 반향세기 차는 확인할 수 없지만, 이러한 결과는 근 손상 시 광범위하게 이용되는 멘톨 성분이 근육 반향세기 증가를 효 율적으로 통제할 수 없다는 사실을 암시한다. 이와 대조적으로 MSM 이 부가된 실험물질을 경피 도포 했을 때 편심성 운동 후 근육 반향세
기는 96시간까지 유의미한 변화를 나타내지 않았을 뿐만 아니라 심지 어 48 시간 이후 점차 감소하는 경향이 나타났다. 사실상 $\mathrm{EIMD}$ 의 증 상 및 징후를 설명하기 위한 여러 간접 표지자들과 마찬가지로 편심성 운동 후 근육 반향세기 역시 EIMD에 대한 반응 양상이 개인에 따라 차이가 크다[34]. 현재 연구의 결과도 EI 반응 값의 개인 간 차이로 인 해 근육 반향세기에서 세션 간 통계적으로 유의미한 차이를 도출하지 는 못했으나, MSM을 부가한 경피 도포 기법이 멘톨 단독 처치에 비해 편심성 운동 후 근 영상학적 변화를 억제할 수 있는 효율적 대안일 가 능성을 시사한다. 따라서 더 큰 표본 집단을 대상으로 추가 검증이 반 드시 수행되어야 할 것으로 생각된다.

현재 연구는 몇몇 제한점을 내포한다. 먼저 젊고 건강한 남성만을 연구대상으로 선별하였기 때문에 현재 연구의 결과는 나이, 성차 및 근 구조생리에 중대한 영향을 미칠 수 있는 병리적 상태를 그대로 반 영할 수 없다. 비록 염증성 근병증 혹은 근이영양증과 같은 병리적 조 건은 인체 근육 재생에 중대한 영향을 미칠 수 있으며 사춘기 이전 어 린이들은 성인들에 비해 근손상에 덜 민감할 수 있지만, 사실상 젊은 사람과 노인 간 또는 남성과 여성 간 근손상에서 차이는 크지 않다 [35]. 그럼에도 불구하고 현재 연구에서는 혼란 요인을 최소화하기 위 해 젊고 건강한 남성으로 연구대상을 제한함으로써 MSM 경피 도포 에 의한 EIMD 반응을 객관적으로 평가하였다. 끝으로 본 연구에서 잠 재적 유효 성분이 완전히 없는 물질의 처치 혹은 아무런 처치를 하지 않은 통제집단을 설정하지 않았기 때문에 대조 물질 즉 멘톨 단독 처 치의 효과를 배제할 수 없다. 현재 연구에서 사용된 실험 물질뿐만 아 니라 대조 물질은 현재 상업적으로 유통되고 있는 시판형 제품이다. 대조물질로써 멘톨이 들어간 제품을 선택한 것은 실험물질 역시 제조 과정상 멘톨을 함유하기 때문에 멘톨 특유의 피부 냉감 혹은 후각 자 극으로 인한 위약효과를 최소화하기 위한 조치였다. 사실상 멘톨 성분 없이 멘톨로 인지되는 감각들을 재현하기는 거의 불가능하므로 멘톨 없는 제품을 통제조건으로 이용할 경우 위약 효과를 피하기가 어렵다. 따라서 본 연구에서는 실험물질의 멘톨 함유량과 동일한 대조물질 제 품을 선택하여 EIMD에 대한 예방 및 회복에 있어서 MSM의 부가 효 과를 과학적으로 밝히고자 하였다.

\section{결 론}

본 실험은 EIMD의 발현 및 회복 과정에 MSM이 미치는 영향을 평 가하기 위해 위약대조의 단일맹검법을 이용한 무작위교차설계를 통 해 실시되었다. 그 결과 MSM 경피 도포에 따라 근육 부종의 발현 약 화, 신전 시 근통증 완화, 근력 감소 완화 및 초음파 반향세기의 증가 완화를 도출하였다. 이와 같은 연구결과를 통해 MSM의 경피 도포가 기존에 널리 사용 중이던 대조물질보다 비교적 EIMD의 발현 및 회복 
에 긍정적인 효과를 미친다는 것을 확인할 수 있었다. 본 연구의 임상 운동의 결과를 토대로, MSM의 경피 도포 적용은 스포츠 현장에서 트 레이닝의 효율성 증가에 기여할 것으로 판단되며, 추후 다양한 연구설 정을 통해 운동으로 유발된 근 손상에 있어 MSM의 유용성을 추가적 으로 평가할 필요가 있을 것으로 판단된다.

\section{CONFLICT OF INTEREST}

Kim MK has received research grants from MSMINERAL company. The other authors have no conflict of interest to declare.

\section{AUTHOR CONTRIBUTIONS}

Conceptualization: MK Kim; Data curation: HD Jo, CS Kim, MK Kim; Formal analysis: HD Jo, CS Kim, MK Kim; Methodology: MK Kim; Project administration: MK Kim; Writing-original draft: HD Jo, CS Kim, MK Kim; Writing-review \& editing: HD Jo, MK Kim.

\section{ORCID}

Hyeon-deok Jo

Maeng-kyu Kim
Choun-sub Kim
https:/orcid.org/0000-0002-7279-153X https://orcid.org/0000-0003-1995-080X https://orcid.org/0000-0002-7855-608X

\section{REFERENCES}

1. Pedersen BK. The physiology of optimizing health with a focus on exercise as medicine. Annu Rev Physio. 2019;81:607-27.

2. Armstrong RB, Ogilvie RW, Schwane JA. Eccentric exercise-induced injury to rat skeletal muscle. J Appl Physiol. 1983;54(1):80-93.

3. Clarkson PM, Hubal MJ. Exercise-induced muscle damage in humans. Am J Phys Med Rehabil. 2002;81(11):S52-S69.

4. Nosaka K, Newton M. Difference in the magnitude of muscle damage between maximal and submaximal eccentric loading. J Strength Cond Res. 2002;16(2):202-8.

5. Howatson G, Van Someren KA. The prevention and treatment of exercise-induced muscle damage. Sports Med. 2008;38(6):483-503.

6. Chen TC, Chen HL, Lin MJ, Wu CJ, Nosaka K. Muscle damage responses of the elbow flexors to four maximal eccentric exercise bouts performed every 4 weeks. Eur J Appl Physiol. 2009;106(2):267-75.

7. Chen TC, Lin KY, Chen HL, Lin MJ, Nosaka K. Comparison in ec- centric exercise-induced muscle damage among four limb muscles. Eur J Appl Physiol. 2011;111(2):211-23.

8. Armstrong RB, Warren GL, Warren JA. Mechanisms of exercise-induced muscle fibre injury. Sports Med. 1991;12(3):184-207.

9. Proske U, Morgan DL. Muscle damage from eccentric exercise: mechanism, mechanical signs, adaptation and clinical applications. J Physiol. 2001;537(2):333-45.

10. Castiglioni A, Corna G, Rigamonti E, Basso V, Vezzoli M, et al. FOXP3+ T cells recruited to sites of sterile skeletal muscle injury regulate the fate of satellite cells and guide effective tissue regeneration. PloS One. 2015;10(6):e0128094.

11. Pasiakos SM, Lieberman HR, McLellan TM. Effects of protein supplements on muscle damage, soreness and recovery of muscle function and physical performance: a systematic review. Sports Med. 2014;44 (5):655-70.

12. Grahame R. Transdermal non-steroidal anti-inflammatory agents. Br Clin Pract. 1995;49(1):33-5.

13. Evans MP, Fleming KC, Evans JM. Hormone replacement therapy: management of common problems. May Clin Proc. 1995;70(8):800-5

14. Gillis DJ, Vellante A, Gallo JA, D'Amico AP. Influence of menthol on recovery from exercise-induced muscle damage. J Strength Cond Res. 2020;34(2):451-62.

15. Eccles R, Griffiths DH, Newton CG, Tolley NS. The effects of D and L isomers of menthol upon nasal sensation of airflow. J Laryngol Otol. 1988;102(6):506-8.

16. Johar P, Grover V, Topp R, Behm DG. A comparison of topical menthol to ice on pain, evoked tetanic and voluntary force during delayed onset muscle soreness. Int J Sports Phys Ther. 2012;7(3):314-22.

17. Butawan M, Benjamin RL, Bloomer RJ. Methylsulfonylmethane: applications and safety of a novel dietary supplement. Nutrients. 2017;9 (3):290.

18. Nakhostin-Roohi B, Barmaki S, Khoshkhahesh F, Bohlooli S. Effect of chronic supplementation with methylsulfonylmethane on oxidative stress following acute exercise in untrained healthy men. J Pharm Pharmacol. 2011;63(10):1290-4.

19. Kalman DS, Feldman S, Scheinberg AR, Krieger DR, Bloomer RJ. Influence of methylsulfonylmethane on markers of exercise recovery and performance in healthy men: a pilot study. J Int Soc Sports Nutr. 2012;9(1):1-11.

20. Withee ED, Tippens KM, Dehen R, Tibbitts D, Hanes D, et al. Effects of Methylsulfonylmethane (MSM) on exercise-induced oxidative 
stress, muscle damage, and pain following a half-marathon: a doubleblind, randomized, placebo-controlled trial. J Int Soc Sports Nutr. 2017;14(1):1-11.

21. Cannavino CR, Abrams J, Palinkas LA, Saglimbeni A, Bracker MD. Efficacy of transdermal ketoprofen for delayed onset muscle soreness. Clin J Sport Med. 2003;13(4):200-8.

22. Manimmanakorn N, Manimmanakorn A, Boobphachart D, Thuwakum W, Laupattarakasem W, et al. Effects of zingiber cassumunar (plai cream) in the treatment of delayed onset muscle soreness. J Integr Med. 2016;14(2):114-20.

23. American College of Sports Medicine. ACSM's guidelines for exercise testing and prescription. Lippincott Williams \& Wilkins 2013.

24. Chen TC, Nosaka K, Sacco P. Intensity of eccentric exercise, shift of optimum angle, and the magnitude of repeated-bout effect. J Appl Physiol. 2007;102(3):992-9.

25. Chen TC, Nosaka K. Responses of elbow flexors to two strenuous eccentric exercise bouts separated by three days. J Strength Cond Res. 2006;20(1):108-16.

26. Ormsbee MJ, Ward EG, Bach CW, Arciero PJ, McKune AJ, et al. The impact of a pre-loaded multi-ingredient performance supplement on muscle soreness and performance following downhill running. J Int Soc Sports Nutr. 2015;12(1):1-9.

27. Ingham SA, van Someren KA, Howatson G. Effect of a concentric warm-up exercise on eccentrically induced soreness and loss of function of the elbow flexor muscles. J Sports Sci. 2010;28(13):1377-82.

28. Pillen S, Arts IM, Zwarts MJ. Muscle ultrasound in neuromuscular disorders. Muscle Nerve. 2008;37(6):679-93.

29. Armstrong RB. Mechanisms of exercise-induced delayed onset muscular soreness: a brief review. Med Sci Sports Exerc. 1984;16(6):52938.

30. Cleak MJ. Delayed Onset Muscle Soreness and Impaired Motor Performance following intense eccentric exercise. Physiotherapy. 1991;77 (7):493.

31. Cramer JT, Beck TW, Housh TJ, Massey LL, Marek SM, et al. Acute effects of static stretching on characteristics of the isokinetic angletorque relationship, surface electromyography, and mechanomyography. J Sports Sci. 2007;25(6):687-98.

32. Fujikake T, Hart R, Nosaka K. Changes in B-mode ultrasound echo intensity following injection of bupivacaine hydrochloride to rat hind limb muscles in relation to histologic changes. Ultrasound Med Biol. 2009;35(4):687-96

33. Matta TT, Pinto RO, Leitão BF, Oliveira LF. Non-uniformity of elbow flexors damage induced by an eccentric protocol in untrained men. J Sports Sci. 2019;18(2):223-8.

34. Burt D, Lamb K, Nicholas C, Twist C. Lower-volume muscle-damaging exercise protects against high-volume muscle-damaging exercise and the detrimental effects on endurance performance. Eur J Appl Physiol. 2015;115(7):1523-32.

35. Hyldahl RD, Chen TC, Nosaka K. Mechanisms and mediators of the skeletal muscle repeated bout effect. Exerc Sport Sci Rev. 2017;45(1): 24-33. 